\title{
Development of a pull-type onion (Allium cepa L.) sowing machine for seedbed
}

\author{
Jessa Austria ${ }^{1 *}$, Romeo Gavino ${ }^{2}$, Helen Gavino ${ }^{2}$ and Marvin Cinense $^{2}$ \\ ${ }^{1}$ Central Luzon State University, College of Engineering, Graduate Student Association, Science City \\ of Muňoz, Nueva Ecija, Philippines and Western Philippines University, College of Engineering and \\ Technology, Department of Agricultural and Biosystems Engineering, San Juan, Aborlan, Palawan, \\ Philippines \\ ${ }^{2}$ Central Luzon State University, College of Engineering, Department of Agricultural and Biosystems \\ Engineering, Science City of Muňoz, Nueva Ecija, Philippines
}

\begin{abstract}
The conventional sowing method of onion seeds offers great wastage and laborious. This study aimed to develop a pull-type onion sowing machine for seedbed to optimize the sowing of seeds, reduce labor cost, yields better quality onion seedlings, and increases income of onion farmers. The machine was tested and evaluated, in comparison with manual sowing of onion seeds, in terms of seed delivery rate, effective field capacity, field efficiency, seeding efficiency and drawbar power. The cost of sowing seeds using the machine was also determined. Results indicated that machine's delivery rate was significantly reduced to $5.33 \mathrm{~g} / \mathrm{m}^{2}$ from $11.35 \mathrm{~g} / \mathrm{m}^{2}$. This resulted to reduction in the quantity of seeds sown for a one-hectare onion production area by about $4-5$ cams (1.6 to $2 \mathrm{~kg}$ ). Machine's field capacity $\left(375.45 \mathrm{~m}^{2} / \mathrm{h}\right)$ was higher than of manual sowing $\left(25.51 \mathrm{~m}^{2} / \mathrm{h}\right)$. Field efficiency at $86.94 \%$ is higher than $60 \%$ threshold given by PAES [3]. The seeding efficiency of $89.70 \%$ was statistically the same with three seeds per $25 \mathrm{~mm}$ hill spacing. The drawbar power was found out to be $0.155 \mathrm{~kW}$. The cost of the machine is $\$ 1,666.67$ with a break-even quantity of $9,226.9 \mathrm{~m}^{2}$ or 138.11 cans of onion seeds in 0.62 years.
\end{abstract}

\section{Introduction}

Onion (Allium cepa L.), locally known as "sibuyas", is commonly used as condiments to add flavor to food. It is one of the important culinary ingredient in the world and considered as medicinal plants used to cure cough, obesity, osteoporosis, diabetes, insomnia, hemorrhoid, constipation, heart disease and other diseases because onions are rich in vitamins and minerals that are essential to our body [4].

The Philippines who ranked 59th among 175 countries in world production of dry bulb onions, has the majority of its produce in Nueva Ecija with 73,911.12 MT or 99.99 percent

\footnotetext{
* Corresponding author: austriajessa@gmail.com
} 
of the region's total output. The onion varieties planted in Nueva Ecija are red onion, yellow or white onion and shallot.

Direct seeding and transplanting are both adopted in the country. In direct seeding, it is planted directly into the field by manual broadcasting at higher seeding rate and labor requirement. Some developed countries uses mechanical direct seeders, however, these are quite expensive and uses high seeding rate. In transplanting, seedlings are started from seed or bulb in a seedbed and transplanted 45 days after sowing. Transplants are noted to have more advantages on economic use of seed, selecting healthy and vigorous seedlings, saving weeding and watering efforts during the early weeks of plant growth, and it also enable the farmers to attend to the seedlings in a compact area [1].

Transplanting is more popular in Central Luzon. The widely cultivated bulb onions, the red creole and yellow granex are grown from seeds, while multiplier onions (shallot or native onion) are raised from bulbs which produce multiple shoots, each of which forms a bulb. About 60.27 percent of the onion farmers cultivate red onion seeds while multiplier onion was planted by 39.73 percent.

In order to reduce the use of seeds for a certain production area, one of the solutions is to practice mechanical sowing of seeds instead of broadcasting where there is usually uneven distribution of seeds. Mechanical sowing of the seeds in the seedbed is necessary in order to distribute uniformly the seeds to produce a relatively uniform size of seedlings, lessen the amount and cost of seeds and man-day requirement of seed sowing. Hence, there is the need to design a seed sowing machine that will be able to sow seeds uniformly to produce robust onion seedlings which can possibly minimize wastage of small and very thin-stemmed seedlings during transplanting operation.

\section{Materials and methods}

\subsection{Design of the machine}

The machine was designed to sow seeds in 18 rows in a well-prepared $1 \mathrm{~m}$ width seedbed, the seed metering mechanism which sow seeds with a spacing of about $8 \mathrm{~mm}$ was groundwheel driven while it is pulled by two-persons on the opposite side of the seedbed. The machine was composed of seven major components, namely: the handle, seed metering, guide wheel, furrow opener, frame, transmission system and furrow closer. The sizes of the different machine elements that comprise the components were designed based on the estimated loads and allowable stresses of the selected materials of construction. Design plan was drawn using Solidworks software.

\subsection{Fabrication of the machine}

Based on the approved design plan, an accredited local machinery fabricator was commissioned to do the fabrication of the machine. Simple and local manufacturing technologies were employed on most of the component parts of the machine. The vertical seed metering plate, however, was fabricated using computer numerical controlled machine (CNC). Step by step processes were: measuring, cutting, and bending of the various parts of the stainless sheet, and angle bar, drilling of holes for bolts, rapid prototyping for seed plate, joining of different assemblies by bolts, nuts, and welding, and assembly of the whole machine, finishing, and painting. 


\subsection{Performance test and evaluation}

Based on the methods of test for agricultural machinery seeder and planter [3], the parameters evaluated included the following: seed delivery rate, effective field capacity, field efficiency, seeding efficiency, and drawbar power. The experiment was set to compare the parameters for the manual seeding and mechanical seeding using the designed onion seeder using t-test comparison after 3 replications for each method.

\subsection{Cost analysis}

The cost analysis included the calculations of annual cost of operation: fixed and variable costs, break-even point, unit cost of sowing seeds using the machine (Php/unit area) and payback period, in case the machine shall be used for custom service operation.

\section{Results and discussion}

\subsection{Description of the manually-operated onion seeder}

The eighteen row onion sowing machine for seedbed as shown in Figure 1 which consists of handle, seed metering, guide wheel, furrow opener, frame, transmission system and furrow closer. The handle is used to pull the machine in both ends, as it was pulled it transmit rotation by chain and sprocket to the seed metering device which is a vertical seed plate which scoops and deliver the seeds into the opened furrow by furrow opener with the aid of guide wheel and followed by furrow closer which covers the seeds being sown.

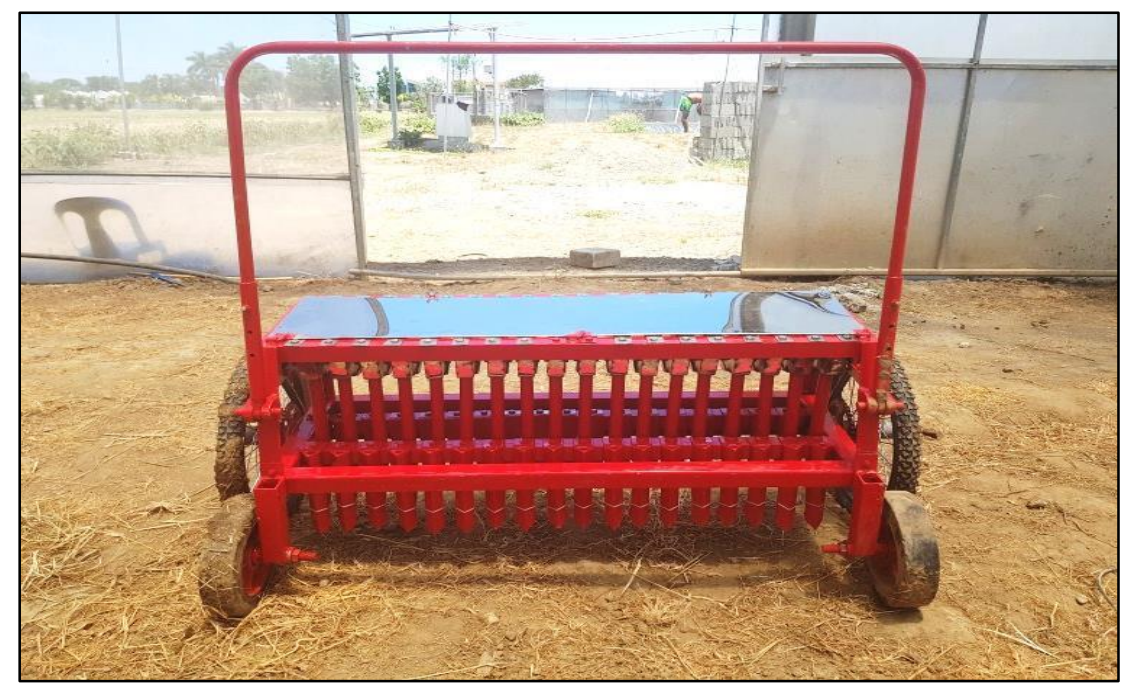

Fig. 1. Onion sowing machine for seedbed.

\subsection{Performance of the machine}

The performance of the machine was summarized in Table 1 . The seed delivery rate of the machine averaged $5.53 \mathrm{~g} / \mathrm{m}^{2}$ and this was significantly lower than manual sowing $(11.35$ $\mathrm{g} / \mathrm{m}^{2}$ ). Sowing seeds in a $400 \mathrm{~m}^{2}$ seedbed, good for one-hectare onion production farm, the difference indicated that the 8-10 cans ( $400 \mathrm{~g} / \mathrm{can})$ of onion seeds sown using the manual 
method was significantly reduced to only about 6 cans of seeds with the use of the mechanical onion seeder. This will cause a reduction of cost of seeds by about $25-40 \%$ in a one-hectare onion production farm.

The mean effective field capacity of manual operation was $25.51 \mathrm{~m}^{2} / \mathrm{h}$ which was significantly lower than that of the mechanical seeding using the machine having a mean capacity of $375.36 \mathrm{~m}^{2} / \mathrm{h}$. The result also trimmed down labor requirement of seed sowing from 16 man-hours for manual method of sowing seeds to only 2.14 man-hours per $400 \mathrm{~m}^{2}$ area of seedbed when the mechanical seeded was used.

In the one-sample t-test analysis of the field efficiency of mechanical sowing when compared with the $60 \%$ required minimum efficiency for tractor power-driven seeder-row crop planter, the result confirmed that the field efficiency of mechanical sowing having a mean of $86.94 \%$ was significantly higher than $60 \%$, hence, in terms of field efficiency, the machine passed the PAES minimum efficiency standard [3]. Likewise, the one sample t-test comparing seeding efficiency of $89.70 \%$ by the machine to the expected seeding efficiency of $100 \%$ ( 3 seeds per $25 \mathrm{~mm}$ ) also indicated that both were statistically equal. It means that seed distribution had an average hill seed spacing of $8 \mathrm{~mm}$ just the same with the desired three seeds in every $25 \mathrm{~mm}$. This result offered at least good quality seedlings assuming other factors to be the same.

The mean seed density of the manual sowing $\left(2863 \mathrm{seeds} / \mathrm{m}^{2}\right)$ was significantly higher than in mechanical sowing $\left(1200 \mathrm{seeds} / \mathrm{m}^{2}\right)$. Considering an onion plant population of 400,000 plants/ha [2], it only needed 1000 seeds $\mathrm{m}^{2}$ in the seedbed and the mechanical seed sowing machine mean seed density was much closer than that in manual sowing. Using the machine would minimize the wastage of unnecessary seeds and low-quality seedlings because of the overcrowding per $\mathrm{m}^{2}$; therefore, a reduction of cost intended for seeds was expected.

The drawbar power of $0.155 \mathrm{~kW}$ exerted by two persons was measured to pull the seed sowing machine. When power exerted by each person was computed, this is slightly higher than the average power of two persons $(0.15 \mathrm{~kW})$ considering the average human power of $0.0746 \mathrm{~kW}(0.1 \mathrm{hp})$ for continuous work.

Table 1. Machine performance versus the manual sowing.

\begin{tabular}{|c|c|c|}
\hline Machine Parameters & Mechanical Sowing & Manual Sowing/Method \\
\hline Seed delivery rate & $5.33 \mathrm{~g} / \mathrm{m}^{2}$ & $11.35 \mathrm{~g} / \mathrm{m}^{2}$ \\
Effective field capacity & $375.36 \mathrm{~m}^{2} \mathrm{~h}$ & $25.51 \mathrm{~m}^{2} \mathrm{~h}$ \\
Field efficiency & $86.94 \%$ & \\
Seeding efficiency & $89.70 \%$ & \\
Seed density & $1200 \mathrm{seed} / \mathrm{m}^{2}$ & $2838 \mathrm{seed} / \mathrm{m}^{2}$ \\
Drawbar power, $\mathrm{kW}$ & $0.155 \mathrm{~kW}$ & \\
\hline
\end{tabular}

\subsection{Cost analysis of the machine}

The onion sowing machine costs $\$ 1,666.67$. Based on the cost of use equation, assumption used (Table 2) and a custom rate of sowing seeds manually at $\$ 0.034 / \mathrm{m}^{2}$, the break-even point (Figure 2) would be when the machine was operated in a seedbed area of $9,227 \mathrm{~m}^{2}$ per 
year. Using the machine for custom service operation at a custom rate of $\$ 0.034 / \mathrm{m}^{2}$ of seedbed area and at annual hours of $264 \mathrm{~h}$ would yield an income of about $\$ 2,678$ per year. Hence, the computed payback period for the investment to be recovered would only be 0.62 years.

Table 2. Calculated data and assumption used for economic analysis.

\begin{tabular}{|c|c|}
\hline Particulars & Total price \\
\hline Purchase price (\$) & $1,666.67$ \\
Salvage value (\%) & 10 \\
n, years & 10 \\
R\&M, \% P/100 h & 5 \\
rate of interest, \% & 10 \\
TIS, \% & 2 \\
Labor cost, P/day & 6.86 \\
Annual hours, h/year & 264 \\
Capacity, $\mathrm{m}^{2} / \mathrm{h}$ & 375.45 \\
\hline A. Fixed cost & \\
Depreciation & 150.00 \\
Int on inv & 91.67 \\
TIS & 33.34 \\
Total annual fc,P/yr & 275.00 \\
\hline B. Variable cost & \\
R \& M & 0.83 \\
Labor & 0.86 \\
Total vc, P/h & 1.69 \\
Break-even point & $9,227 \mathrm{~m}^{2} / \mathrm{yr}$ \\
\hline
\end{tabular}

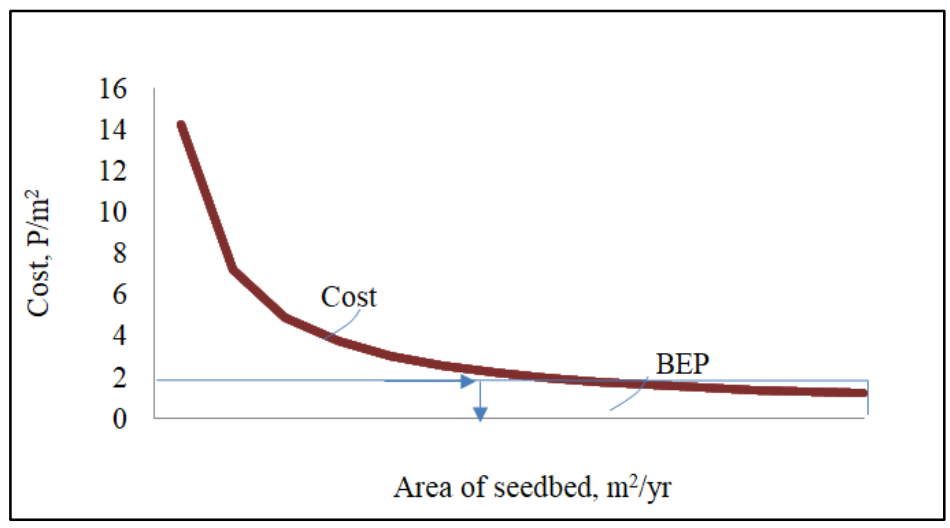

Fig. 2. Cost curve of using the machine.

\section{Conclusions}

Based on the results of the study, the following conclusions were made:

1. The concept and mechanism of developed onion sowing machine have proven to be effective to reduce labor, time, and use of seeds;

2. It can be fabricated using locally available materials at local machine shop except for the seed plate made by Computer Numerical Control; 
3. Seed delivery rate was $5.33 \mathrm{~g} / \mathrm{m}^{2}$ which is lesser compared to manual accounting to 11.35 $\mathrm{g} / \mathrm{m}^{2}$. Effective field capacity for manual sowing was $25.51 \mathrm{~m}^{2} / \mathrm{h}$, and $375.45 \mathrm{~m}^{2} / \mathrm{h}$ using the machine. Field efficiency of onion sowing machine garnered $86.94 \%$ while seeding efficiency was $89.7 \%$; and,

4. The total actual cost of fabrication of the machine is $\$ 1,666.67$. It will be needed to sow $9,227 \mathrm{~m}^{2}$ in a year to break-even the cost; enough to return the investment in one year.

\section{References}

1. S. Ketema, L. Dessalegn, B. Tesfaye, EJAS 24, 1 (2013)

2. C. Shock, E. B. G. Feibert, L. Saunders, OSU Agricultural Experiment Station Ext/CrS 144 (2013)

3. Philippinev Agricultural Engineering Standard. Agricultural Machinery - Seeder and Planter - Methods of Test. PAES, 123 (2001)

4. Philippine Statistics Authority, 2013, Cost and Returns Survey of Onion Production (2014) 